\title{
Tre chiese a Trieste: per un'analisi grafica comparativa
}

\author{
Alberto Sdegno \\ Silvia Masserano \\ Veronica Riavis
}

Abstract

Obiettivo dello studio è stato analizzare tre opere di architettura che bene esprimessero i temi proposti, vale a dire l'idea di connessione, da un lato, e i tre concetti di linguaggio, distanza e tecnologia, dall'altro.

La ricerca ha quindi previsto l'individuazione di tre architetture significative di ambito religioso, connesse tra loro dalla uguale funzione liturgica, e da un forte legame in senso spaziale (essendo tutte realizzate in area triestina) e temporale (costruite nell'arco di meno di un ventennio nel secondo dopoguerra). Allo stesso tempo si sono rilevati caratteri dalla forte dissomiglianza, sia sul piano morfologico, sia su quello della prossimità/lontananza, sia, infine, sui modi in cui sono state descritte figurativamente, nel corso dell'analisi delle geometrie e delle configurazioni spaziali.

I tre casi studio - il Santuario alla Beata Vergine Maria sul Monte Grisa di Antonio Guacci, la chiesa dell'Immacolato Cuore di Maria di Umberto Nordio e il centro parrocchiale in Borgo San Sergio di Ernesto Nathan Rogers - offrono, pertanto, un significativo esempio di sintesi del dissimile, che mostra come i caratteri di un'opera possano veicolare sensazioni molto diverse tra loro, pur insistendo, in uno stesso periodo di tempo, su di un medesimo ambito territoriale e soprattutto avendo uguale funzione.

Parole chiave

Trieste, chiesa, disegno, analisi grafica, modellazione digitale.

Le tre chiese analizzate: da sinistra: il Tempio (elaborazione grafica E.Widmar); la chiesa dell'Immacolato Cuore di Maria di U. Nordio (elaborazione grafio (elaborazione grafica V. Riavis), la chiesa in Borgo S. Sergio di E.N. Rogers (elaborazione grafica S. Masserano).
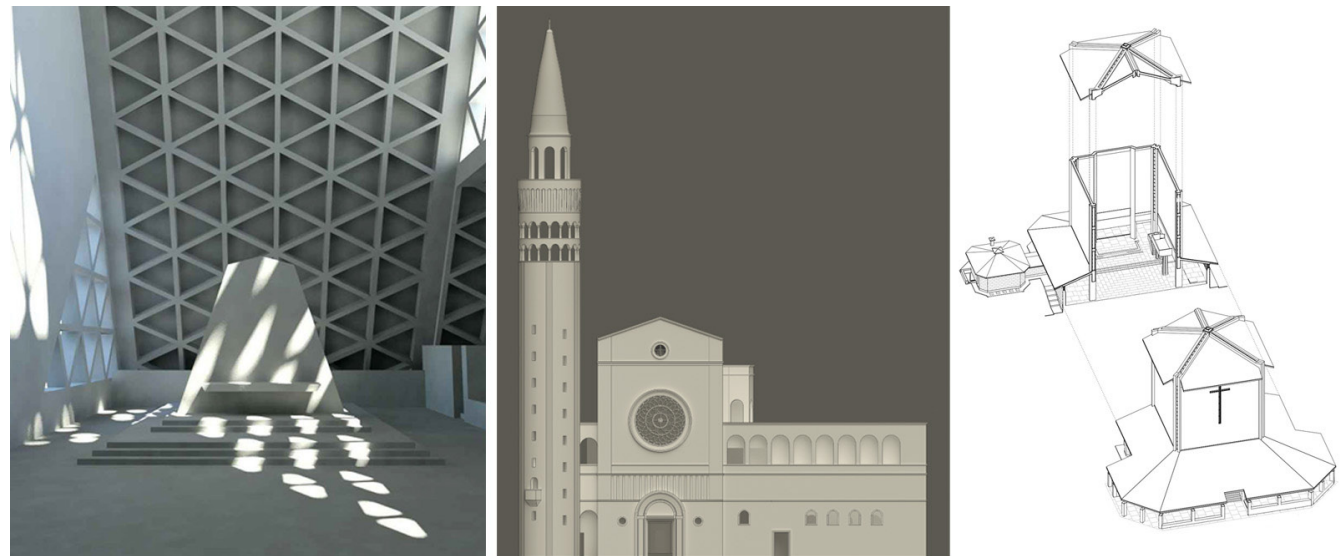


\section{Introduzione}

È possibile declinare in senso architettonico le tre tematiche del linguaggio, della distanza e della tecnologia? L'occasione ci viene offerta da una ricerca attualmente in corso sul patrimonio edilizio del Novecento in area triestina, di cui il lavoro qui presentato risulta essere un primo esito. A valle di una catalogazione di un cospicuo numero di opere, finalizzata a un'indagine grafica sui disegni e sulla forma architettonica, sono stati individuati tre significativi esempi di ambito religioso, che bene si offrono a rappresentare le differenti declinazioni offerte dai tre temi. Si tratta del santuario sul Monte Grisa, della chiesa dell'Immacolato Cuore di Maria e della chiesa in Borgo San Sergio.

Dal punto di vista del 'linguaggio' figurativo esse rispondono a canoni linguistici molto diversi, che dipendono molto dalla sensibilità dei progettisti. II santuario, infatti, è opera di Antonio Guacci, un ingegnere-artista attento alla morfologia complessiva di un'opera tanto da sottolineare gli aspetti scultorei che la luce e l'ombra determinano sulla forma, come si può notare anche in altre sue significative opere, tra le quali l'edificio $\mathrm{Cl}$ nel complesso universitario di Trieste. La seconda chiesa, progettata da Umberto Nordio - prolifico architetto giuliano - risponde a canoni più tradizionali, sebbene declinati con forme e materiali diversi. Sviluppo longitudinale della navata, campanile e parti accessorie riflettono consuete sensibilità del periodo, evidenti anche in altre architetture, quali ad esempio l'edificio principale dell'università in piazzale Europa. La terza opera è di uno dei più influenti architetti del $X X$ secolo: Ernesto Nathan Rogers. Noto per essere uno dei fondatori dei BBPR - formato, oltre che dallo stesso, da Gian Luigi Banfi (che morirà nel campo di concentramento di Gusen), Lodovico Barbiano di Belgiojoso ed Enrico Peressutti - Rogers otterrà questo incarico grazie alle sue origini triestine, sviluppando la soluzione che poi verrà realizzata.

Pur essendo tutte costruite nell'arco di pochi anni - indicativamente tra gli anni Cinquanta e la metà degli anni Sessanta del secolo scorso - esse sono molto dissimili tra loro, tanto da rendere difficile anche una comparazione. Tale 'distanza' formale è poi confermata anche dalla loro 'distanza fisica', dal momento che sono collocate in punti diversi dell'area triestina. II santuario, infatti, è collocato a nord della città, a circa 330 m di altezza, dal quale si offre allo sguardo di tutti coloro che arrivano a Trieste; 'l'mmacolato Cuore è in centro città, vicino alla stazione e a pochi passi da Piazza Unità d'Italia, al centro di una ideale circonferenza avente come raggio la distanza tra gli altri due casi studio, vale a dire circa dieci chilometri. La chiesa di Rogers, infatti, è collocata nel quartiere periferico a sud della città, verso il confine sloveno in direzione di Capodistria.

Dal punto di vista della 'tecnologia' si è optato per una netta differenziazione anche in termini di analisi grafica. Nel primo caso si è deciso di analizzare l'opera facendo uso di algoritmi di simulazione dell'illuminazione naturale che potessero rendere esplicite le intenzioni del progettista e il carattere specifico dell'opera, attraverso immagini di sintesi che potessero emulare la percezione prospettica del visitatore. La luce del sole, infatti, determina particolari effetti chiaroscurali che denotano l'attenzione dell'architetto nello studio delle forme e l'impiego di tali algoritmi consente di visitare virtualmente l'architettura come se ci trovassimo contemporaneamente in vari periodi dell'anno o del giorno.

Nel secondo caso si è voluto sottolineare la forma plastica dell'opera per poter esaltare i singoli elementi - il corpo di fabbrica principale, il campanile cilindrico, ecc. - in una modalità oggettiva, attraverso l'impiego di rappresentazioni astratte a centro di proiezione improprio - ortogonali e assonometriche - nella forma di immagini a colori, per sottolineare anche il tessuto cromatico delle superfici.

Nel terzo caso si è mantenuta una forma ancora più astratta - dettata dal semplice disegno di linee al tratto - che potesse interpretare al meglio la sensibilità del progettista e allo stesso tempo descrivere anche quelle parti non realizzate - come il campanile - del quale non si hanno informazioni dettagliate sul colore della superficie. La volontà di sottrarre l'opera da una compiuta descrizione dei materiali ha avuto un ulteriore sviluppo nella creazione di un modello solido in prototipazione rapida che, pur permettendo una materializzazione fisica, restituisse la forma nella sua essenzialità geometrica - anche attraverso l'impiego di una scomposizione per parti dell'architettura. 
Pur essendoci una forte 'connessione' tra loro a causa della medesima finalità progettuale - lo svolgersi di funzioni religiose al loro interno - le tre opere mostrano dissimili connotazioni sui tre aspetti che abbiamo considerato - il 'linguaggio, la distanza e la tecnologia' declinati sul livello che più ci interessa, vale a dire il settore di indagine del disegno.

\section{II santuario alla Beata Vergine Maria sul Monte Grisa (1959-1966)}

Una strana forma tronco-piramidale è visibile sulla cresta collinare del Monte Grisa a coloro che, viaggiando in treno o in automobile, giungono a Trieste. La posizione è sicuramente uno degli elementi più caratteristici del progetto, grazie alla quale il contenuto a serialità triangolare del prospetto viene sicuramente esaltato.

Le vicende relative alla realizzazione sono ben note, grazie a una serie di contributi già pubblicati (Walker 1977, Guacci 199I). In estrema sintesi ricordiamo che si tratta di un Tempio dedicato alla Vergine Maria, al quale il suo autore - Antonio Guacci - ha riservato molte energie. Sebbene tra gli autori sia indicato anche Umberto Nordio, che ha di fatto soltanto coordinato il progetto, in realtà Guacci deve essere considerato l'ideatore dell'opera, basata su di una doppia matrice geometrica: la pianta, infatti, è regolata da una serie di quadrati di 5 metri di lato, mentre il prospetto è formato da ben 288 triangoli isosceli, aventi la particolarità di avere la base e l'altezza uguale a 2,5 metri. In questo modo quadrato e triangolo pur essendo geometrie molto differenti - risultano essere mutuamente relazionate tra loro. Bisogna anche ricordare che il triangolo prescelto è realizzato sulla base delle indicazioni date dal matematico Leonardo Eulero nel ' 700 , vale a dire è costruito in modo ricorsivo unendo i punti medi delle distanze tra l'ortocentro e i vertici di un triangolo avente i lati

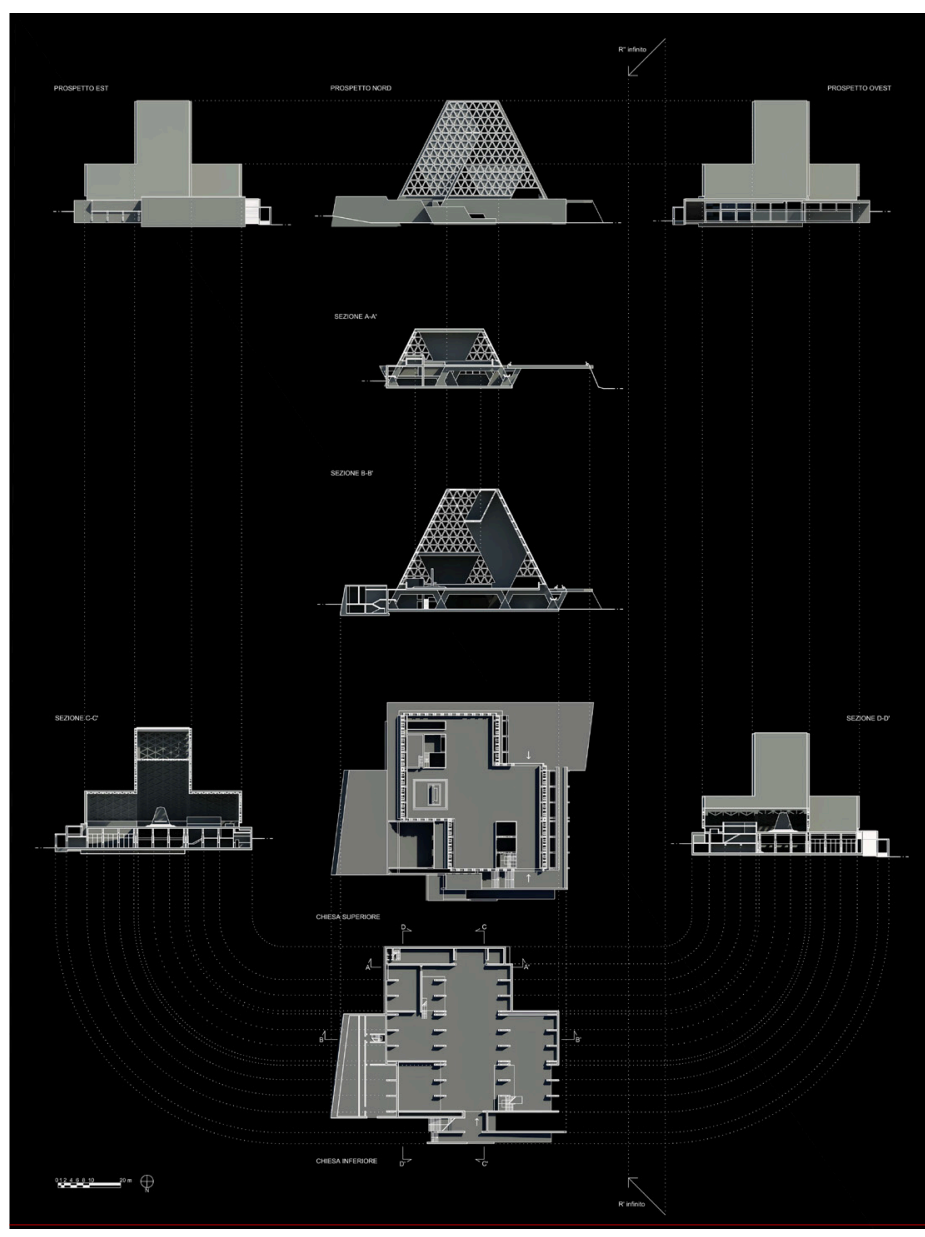


Fig. 2. Sistema di simulazione della luce naturale del Tempio Mariano

con algoritmi di Global

Illumination (elaborazione grafica E. Widmar).

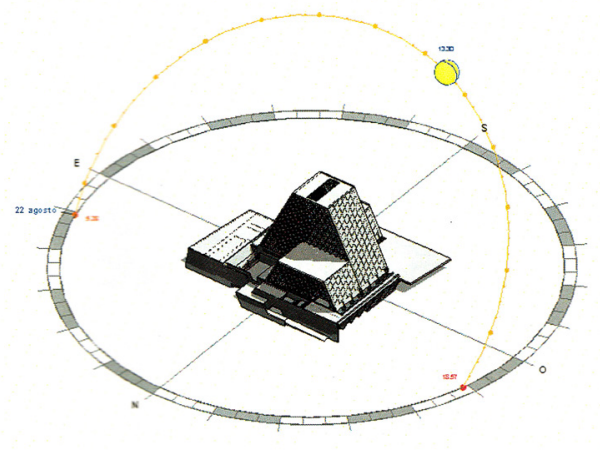

uguali al doppio dei lati del triangolo ottenuto, essendo quest'ultimo perfettamente inserito al centro di quello iniziale.

La chiesa è costruita come un blocco in cemento armato gettato in opera, realizzato grazie alla collaborazione di Sergio Musmeci per il calcolo delle strutture e il plauso di Adalberto Libera e Luigi Moretti, in qualità di membri della Pontificia Commissione Centrale per l'Arte Sacra in Italia, la quale in data I I dicembre 1963 ha approvato il progetto, permettendone la realizzazione.

Tra gli elementi significativi è da ricordare la cella campanaria che, rivolta verso l'interno, costituisce una novità progettuale, non essendo collocata in posizione sommitale e esterna come avviene di solito con l'inserimento nei campanili.

Dall'alto dei suoi 330 metri sul ciglione carsico, il Tempio domina il golfo di Trieste e, pur essendo distante dal centro della città, di fatto è tra le opere più amate dai triestini, grazie anche alla straordinarietà delle sensazioni che il gioco di luci trasmette ai fedeli nel corso dell'anno e della giornata. Una particolarità che si è voluta analizzare in dettaglio con l'impiego di algoritmi di illuminazione avanzata che hanno permesso di simulare in maniera verosimile la luce solare che si diffonde sull'altare in determinati periodi dell'anno e del giorno.

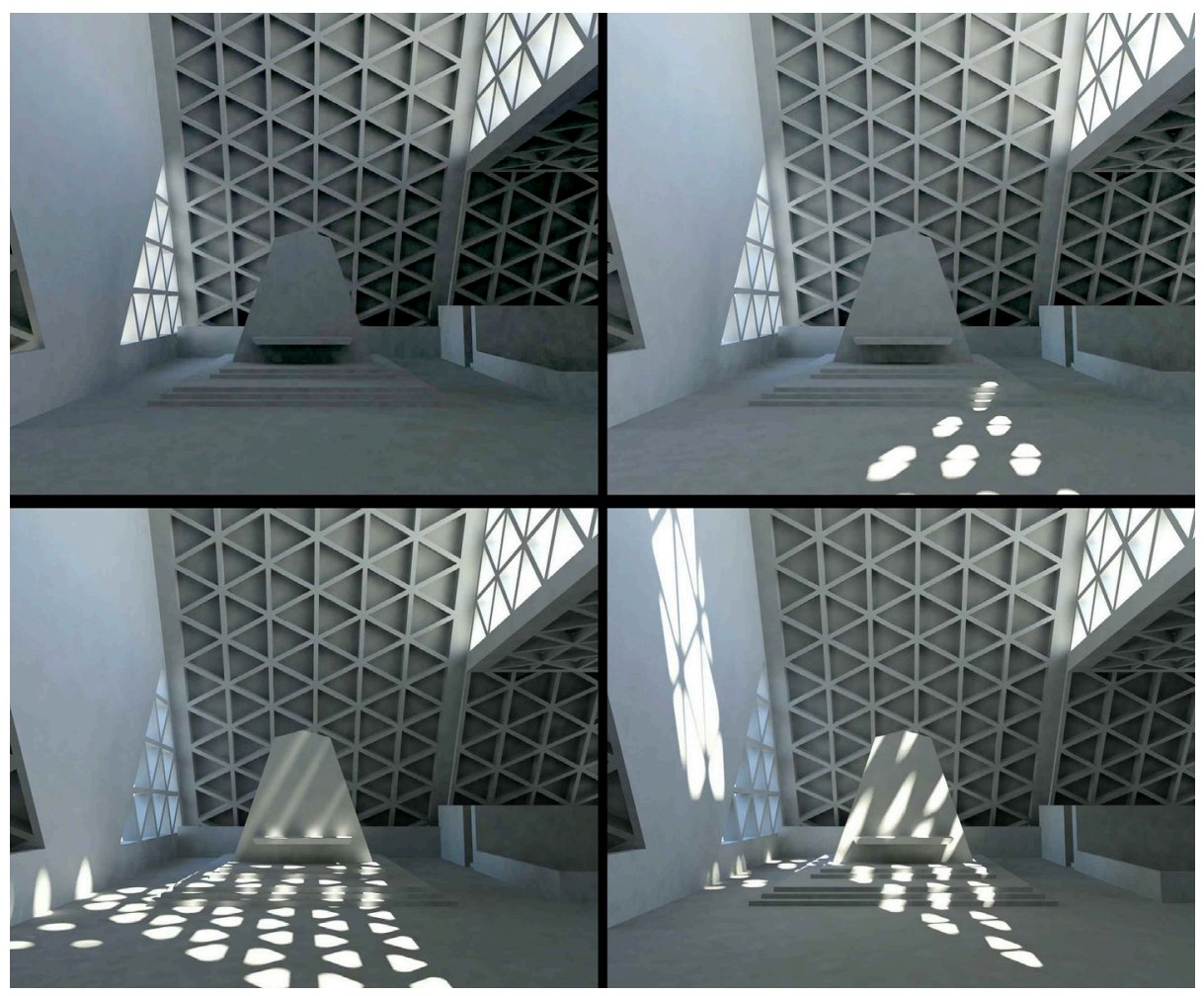

Fig. 3. Simulazione della luce naturale sull'altare del Tempio Mariano in vari periodi della giornata con algoritmi di Global Illumination (elaborazione grafica E.Widmar). 


\section{La chiesa dell'Immacolato Cuore di Maria (1940-1955)}

All'angolo delle vie Sant'Anastasio e Manna si trova la chiesa dedicata all'Immacolato Cuore di Maria progettata da Umberto Nordio (1891-197I). L'architetto triestino laureatosi a Milano nel 1919, progettò diverse destinazioni d'uso edilizie. II suo operato si estese dal Ventennio al secondo dopoguerra, e talvolta le sue opere subirono rallentamenti causati dal conflitto mondiale come nel caso di questa chiesa, il cui progetto di massima fu inoltrato nel 1940, con la consacrazione dell'opera nel 1955, nonostante fosse ancora incompleta del campanile ultimato negli anni Settanta.

In questo edificio Nordio integra il gusto novecentista ai caratteri formali e funzionali della basilica delle origini. Analogamente a quanto applicato ad altri contesti progettuali, le sue architetture privilegiano la composizione di volumi semplici, la reinterpretazione in chiave contemporanea di tradizioni risalenti a diverse epoche e l'utilizzo di materie prime locali. La chiesa a pianta basilicale è suddivisa in tre navate con conclusione absidale. L'ambiente è scandito da arcate sorrette da semplici colonne di un ordine simile al tuscanico privo di piedistallo e trabeazione. Le navate laterali sono coperte da volte a crociera e a botte, mentre quella centrale presenta un profilo a sezione ellittica definita da nervature e arcate. Priva di matronei, la navata centrale è illuminata dalle alte finestre del cleristorio [I].

Nel presbiterio Nordio pensa di inserire un pulpito accessibile da due semplici scale laterali, elemento assente nella configurazione attuale dell'edificio.

Il prospetto principale su via Sant'Anastasio richiama le basiliche romaniche: la facciata a capanna cela la conformazione interna delle navate e un unico portale strombato sormontato dal mosaico della Vergine con il Bambino introduce all'edificio. II prospetto laterale su via Manna è invece scandito da archi ciechi in corrispondenza delle campate delle navate laterali.

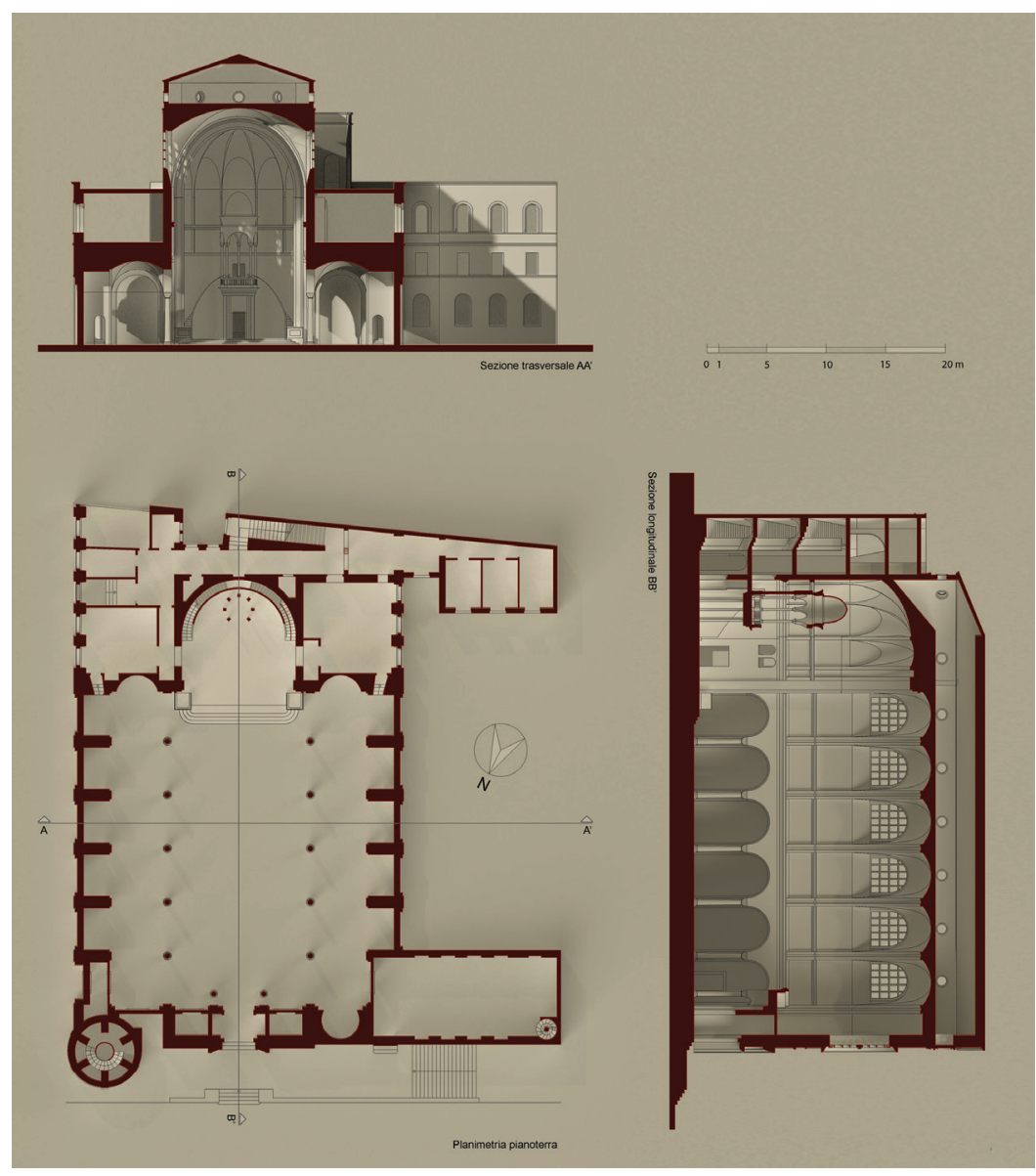


Fig. 5. Sezioni planimetriche e altimetriche della chiesa dell'Immacolato Cuore di Maria (elaborazione grafica V. Riavis).

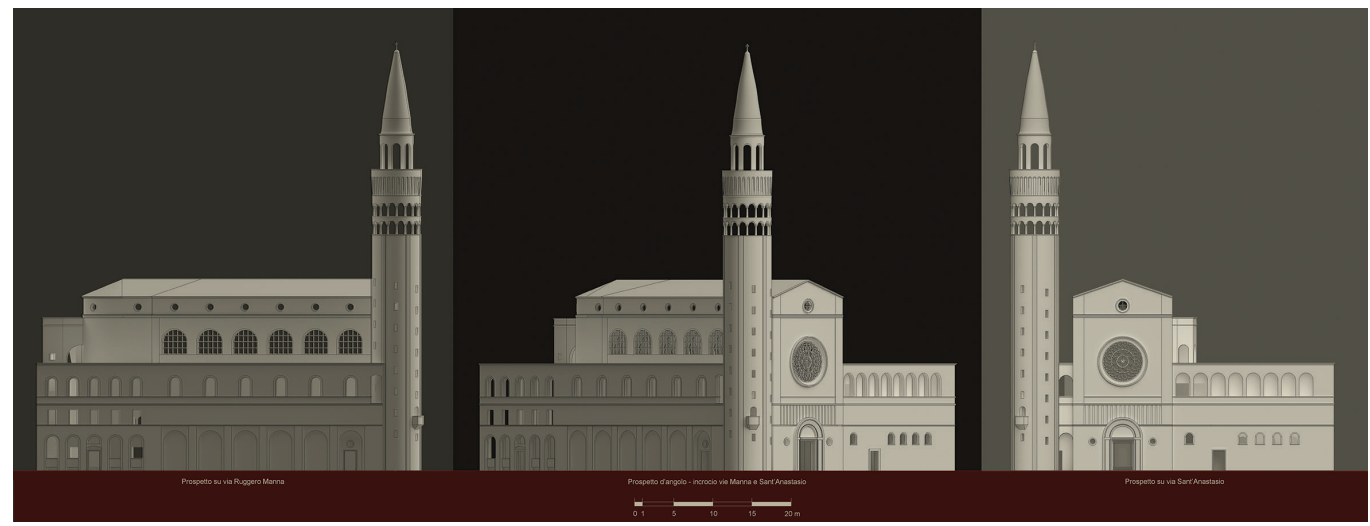

All'esterno il rivestimento orizzontale in conci lapidei è interrotto verticalmente da fasce decorative, ma l'attenzione è catturata soprattutto dal grande rosone che pare richiamare quello della basilica triestina di San Giusto, e dall'alta torre campanaria aggettante a pianta circolare che si conclude con diversi registri loggiati.

Le interessanti geometrie e scelte progettuali sono state evidenziate ricostruendo la chiesa e l'annesso convento basandosi sui disegni originali di Nordio. La modellazione ha consentito di comprendere maggiormente la distribuzione e l'interazione tra i due spazi dalla differente funzione, ma anche di gestire il modello digitale secondo diverse viste e di approfondirne i caratteri compositivi e proporzionali, come la struttura delle campate o elementi non realizzati del pulpito. La complessità dell'edificio, dei suoi volumi e contenuti è resa evidente grazie all'impiego di proiezioni parallele che consentono di accompagnare alle figure una restituzione metrica, tale da consentire la misurazione dei disegni. Proiezioni mongiane e assonometrie ortogonali isometriche riescono a rappresentare al meglio la complessità morfologica di questa significativa architettura triestina.
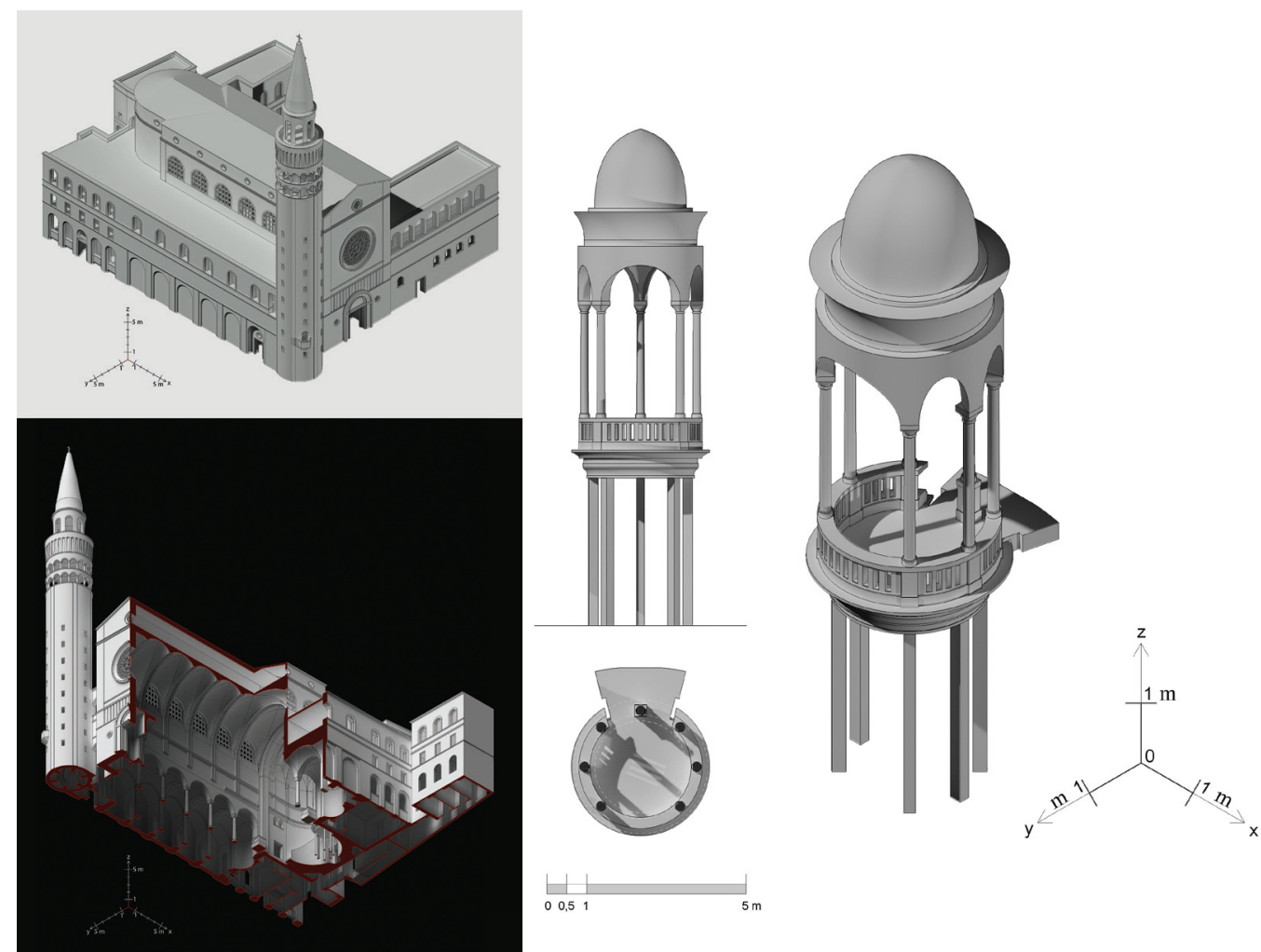

e assonometria de progetto del pulpito della chiesa dell'Immacolato Cuore di Maria

(elaborazione grafica $\mathrm{V}$. Riavis).
Fig. 6. Assonometrie ortogonali isometriche della chiesa

dere di Maria (elaborazione grafica V. Riavis). 


\section{Il centro parrocchiale di Borgo San Sergio (1954-|967)}

Il progetto del quartiere operario di Borgo San Sergio, previsto nel 1949 dal Piano regolatore della zona industriale di Trieste, prevedeva oltre alla realizzazione di edifici residenziali un polo di servizi. Nello svolgimento complessivo del piano, i BBPR si occuparono dell'elaborazione tecnica e della parziale esecuzione di alcuni elementi del centro comunitario e della chiesa dedicata a San Sergio. II progetto dell'edificio liturgico, messo in opera nel I967, giunse a completa definizione solo al termine di un iter segnato da una sequenza di cinque ipotesi redatte da Ernesto Nathan Rogers.

Una prima idea della chiesa è espressa in uno schizzo elaborato nel 1954 e definisce a grandi linee l'edificio come un organismo autonomo, in cui un complesso di volumi delimitati da un porticato sono accomunati dallo sviluppo della copertura. La seconda proposta - datata 1955 - configura la chiesa mediante un impianto poligonale affiancato da un campanile, mentre la terza delinea nel 1960 un'organizzazione prossima alla soluzione definitiva, owvero un edificio ove due sistemi di copertura concludono l'aula a un'unica navata e un portico circoscritto alla sola zona d'accesso, e dove la conformazione del campanile viene ridotta a impalcatura strutturale. La quarta variante configura nel 196I una chiesa racchiusa dall'incrocio di un sistema di portali in cui il volume intero non si traduce come un'immensa e generica cubatura, ma come una realtà differenziata e fluente ove la luce proveniente dalle grandissime vetrate (una delle quali studiata per illuminare l'altare) contribuisce al raggiungimento di questo risultato; anche il campanile è modellato con lo stesso schema strutturale della chiesa, nel tentativo di ridurre gli effetti derivanti dall'esposizione al vento di bora. $\mathrm{Nel}$ 1962 la versione definitiva conduce a compimento il progetto della chiesa: nella quinta proposta l'edificio, pur rimanendo a grandi linee invariato rispetto alla soluzione del 196I, presenta alcuni riadattamenti dovuti a una maggiore definizione del dettaglio. II tamponamento del portico si abbassa liberando i pilastri che costituiscono l'unico appoggio per la copertura del porticato. Lo sviluppo trasversale dell'impianto planimetrico viene dilatato adducendo un sensibile ampliamento allinvaso centrale, mentre la traslazione verso il centro del presbiterio della scala del coro concede l'inserimento delle rampe che collegano verticalmente l'interno della navata. La pavimentazione riprende la geometria dell'aula sottolineando, in corrispondenza della proiezione dell'invaso sul piano di calpestio, le diagonali di due esaedri per mezzo di piastrelle di diversa cromia. Una maggiore distanza separa i doppi telai e au-

Fig. 8. Pianta, sezioni ed esploso assonometrico della prima versione (1960) del progetto di Ernesto Nathan Rogers per la chiesa di Borgo S. Sergio (elaborazione grafica S. Masserano).

Fig. 9. Pianta, sezioni ed esploso assonometrico della seconda versione (1961) del progetto per gio (elaborazione grafica gio (elaborazione grafica
S. Masserano).
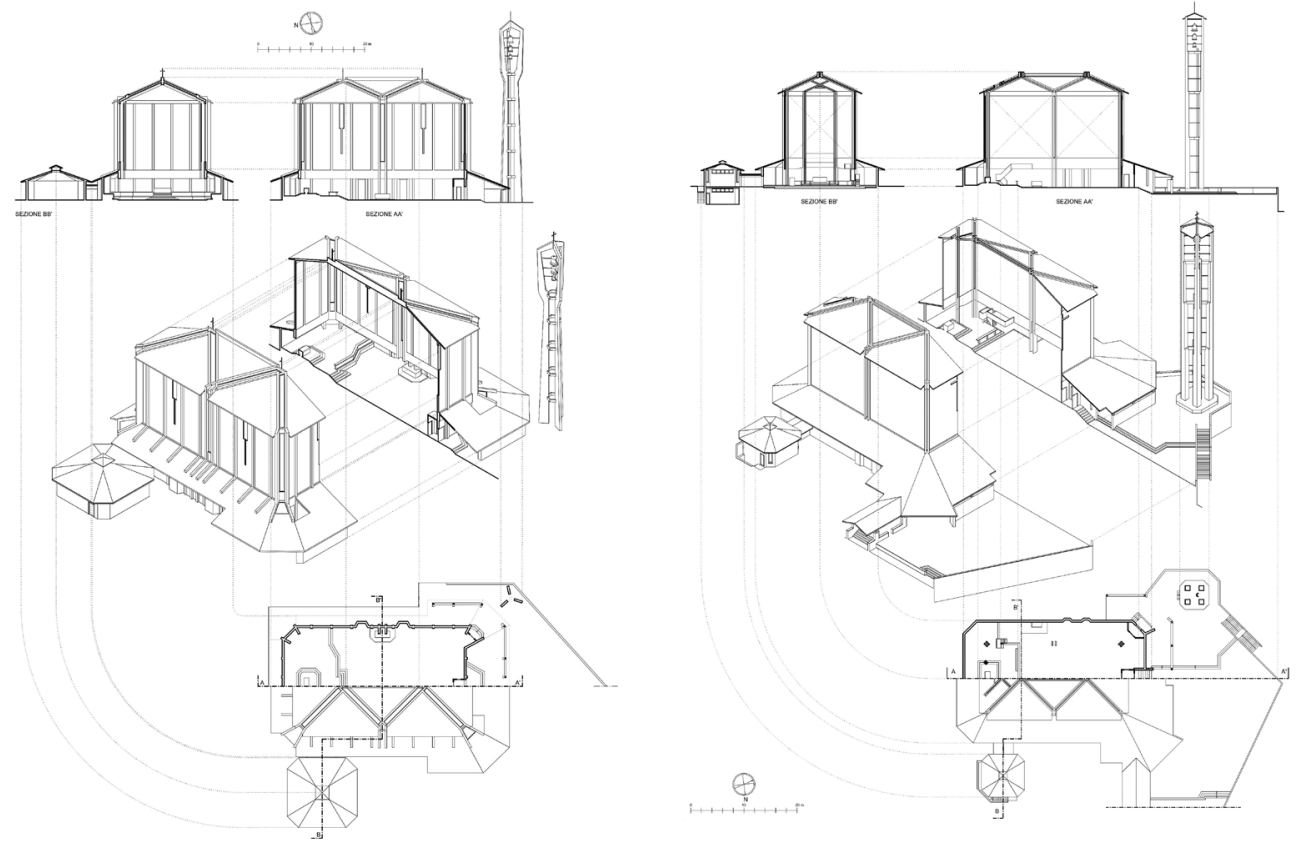
Fig. 10. Pianta, sezioni ed esploso assonometrico della versione realizzata (1962) della chiesa di Borgo S. Sergio (elaborazione grafica S. Masserano).

Fig. II. Sequenza assonometrica degli elementi costruttivi e assonometrie della versione realizzata (1962) della chiesa di Borgo S. Sergio (elaborazione grafica S. Masserano).
Fig. 12. Modello fisico sezionato della versione realizzata (1962) della chiesa di Borgo S. Sergio chiesa di Borgo S. Sergio realizzato con tecniche di prototipazione rapida (elaborazıone grafica S. Masserano).
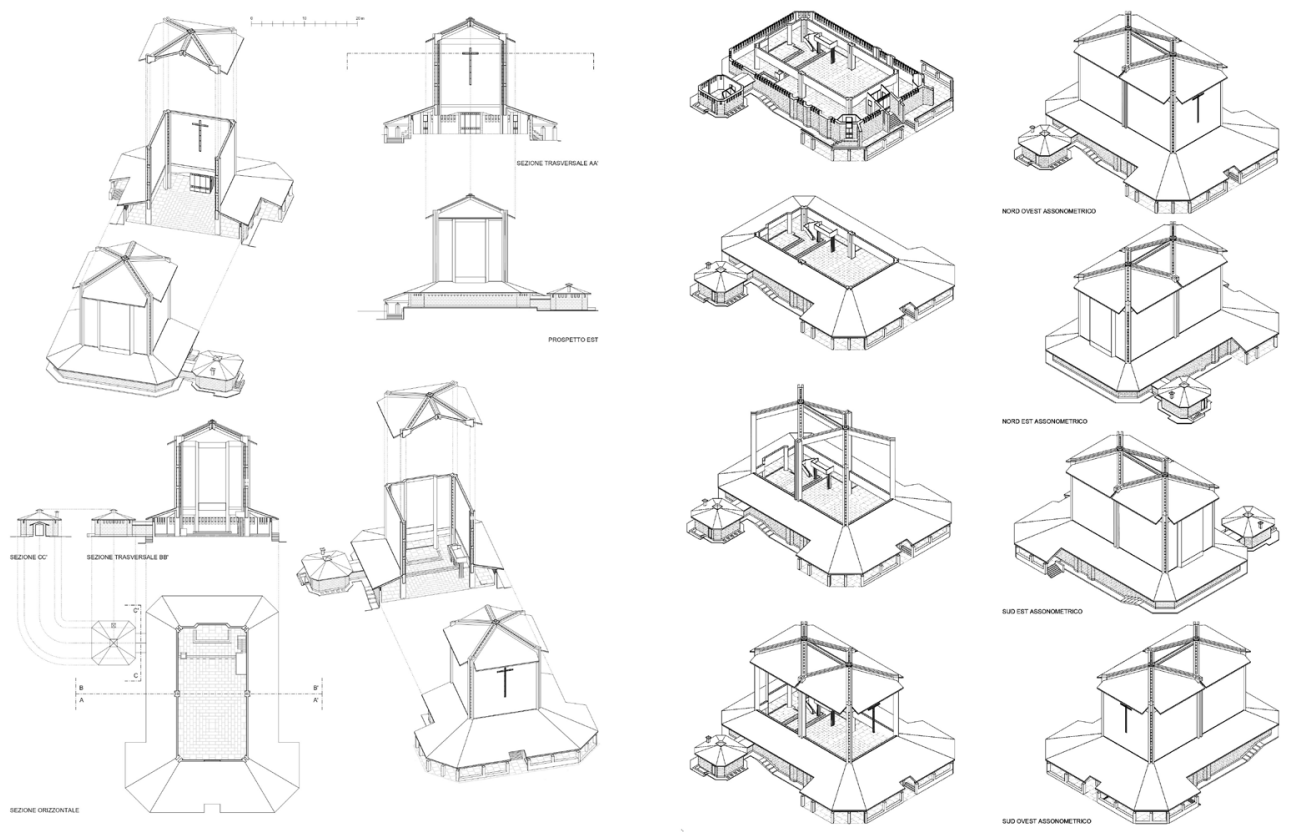

menta la luminosità derivante dall'impiego di una più ampia superficie vetrata. La quantità di luce diurna dell'ambulacro viene amplificata dalla presenza di una serie di finestre-feritoie per compensare le tonalità generate dalla presenza, tra i portali in calcestruzzo a vista, delle duplici vetrate policrome. La soluzione del lucernaio sopra l'altare viene eliminata e con essa la relativa struttura di sostegno. Durante la messa in opera, al progetto vengono apportate delle alterazioni e immessi degli elementi supplementari non anticipati dalle rappresentazioni grafiche.

La ricostruzione dei modelli digitali delle ultime tre proposte ha permesso di visualizzare aspetti non contemplabili dalla tradizionale documentazione grafica e cogliere in modo completo l'evoluzione di un'idea progettuale, anche impiegando le nuove tecnologie di prototipazione rapida che hanno fornito ulteriori informazioni per la comprensione dello spazio fisico.

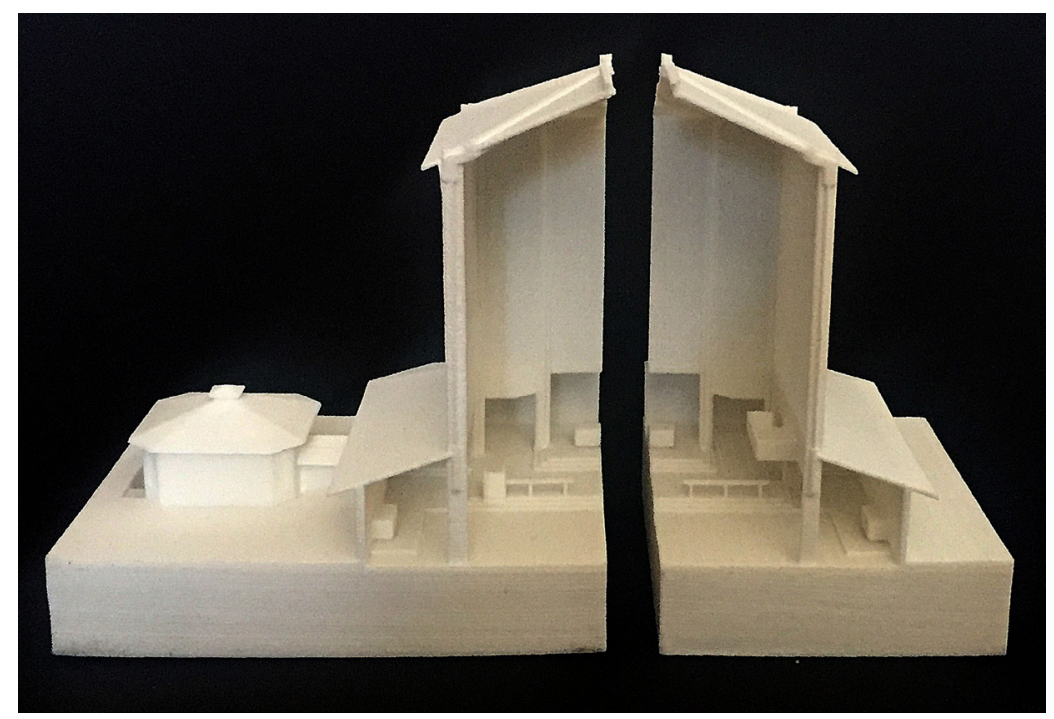




\section{Conclusioni}

L'analisi ho permesso di confrontare tre opere aventi forti legami sul piano funzionale - essendo tre chiese tutt'ora consacrate a destinazione liturgica - realizzate nell'area triestina in un medesimo periodo storico. Come si è visto, però, la loro collocazione è fortemente dissimile e soprattutto sono connotate da una notevole difformità morfologica. Tettonica, materiali e geometria le rendono opere da un forte carattere distintivo che abbiamo cercato di sottolineare anche figurativamente con l'impiego delle tecnologie avanzate, facendo uso di algoritmi di simulazione verosimile per il Tempio di Antonio Guacci, di immagini di sintesi in proiezione parallela per la chiesa di Umberto Nordio, e di geometrie al tratto - affiancate dalla materialità di una stampa 3D - per il centro parrocchiale progettato da Ernesto Nathan Rogers, in modo che i tre concetti di linguaggio, distanza e tecnologia potessero essere interconnessi tra loro.

\section{Note}

[I] Le navate laterali non presentano finestre e sono illuminate artificialmente.

\section{Riferimenti bibliografici}

Beari G. (1960). Guida alle chiese di Trieste e provincia. Trieste: Stab. Tipografico nazionale.

Ceiner G. (1998). Antonio Guacci. 19 I 2-1995. II di-segno di una vita.Trieste: Lint.

Ceiner G. (2005). La creatività di Antonio Guacci tra arte e architettura. In L'archeografo triestino, vol. 65, n. I I 3, pp. 3 I 5-346.

Contessi G. (1981). Umberto Nordio. Architettura a Trieste 1926-1943. Milano: Franco Angeli.

Coppo D., Pozzetto, M. (a cura di) (1 987). Disegni d'architettura di Antonio Guacci.Trieste:Tip.Villaggio del Fanciullo.

Cuscito G. (1982). Storia di Trieste Cristiana attraverso le sue chiese. Trieste:Vita nuova.

Guacci A. (1956). La storia ed i caratteri degli edifici.Trieste:Tip. Smolars.

Guacci A. (199|). Il tempio di Monte Grisa a Trieste. Trieste: Del Bianco.

López Reus M. E. (2009). Ernesto Nathan Rogers. Continuità e contemporaneità. Milano: Marinotti.

Mainati E. (20 I8). Perché sorse il Tempio di Monte Grisa e i suoi primi passi. In L'Archeografo triestino, vol. 78, pp. 6-24.

Montesi P. (a cura di) (198I). Antonio Guacci. Disegni di architettura. Trieste: Edizioni Moderna.

Nicoloso P., Rovello F. (2005). Trieste 1918-1954. Guida all'architettura. Trieste: MGS Press.

Nordio U. (1955). Edilizia triestina vista da un architetto.Trieste:Tip. Giuliana.

Rogers E.N. (2006). Gli elementi del fenomeno architettonico. Milano: Marinotti.

Rogers E. N., Montesi P., Costa R. (1962). Tre interventi sul piano regolatore generale di Trieste. Udine: Del Bianco.

Sdegno A. (20|2). Unbuilt Rogers. II disegno di progetti non realizzati dei BBPR. In C. Baglione (a cura di). Ernesto Nathan Rogers 1909-1969. Milano: Franco Angeli.

Walcher M. (1989). II tempio mariano di Monte Grisa. La storia e l'architettura. Trieste: Italo Svevo.

Zerboni M., Moro L. (2016). La storia del Tempio nazionale di Monte Grisa dedicato a Maria Madre e Regina. Trieste: Luglioprint.

\footnotetext{
Autori

Alberto Sdegno, Università degli Studi di Udine, alberto.sdegno@uniud.it

Silvia Masserano, Università degli Studi di Trieste, smasserano@units.it

Veronica Riavis, Università degli Studi di Udine, veronica.riavis@uniud.it.
}

Per citare questo capitolo: Sdegno Alberto, Masserano Silvia, Riavis Veronica (2021). ITre chiese a Trieste: per un'analisi grafica comparativa/Three churches in Trieste: for a comparative graphic analysis. In Arena A., Arena M., Mediati D., Raffa P. (a cura di). Connettere. Un disegno per annodare e tessere. Linguaggi Distanze Tecnologie. Atti del $42^{\circ}$ Convegno Internazionale dei Docenti delle Discipline della Rappresentazione/Connecting. Drawing for weaving relationship. Languages Distances Technologies. Proceedings of the $42^{\text {th }}$ International Conference of Representation Disciplines Teachers. Milano: FrancoAngeli, pp. I| $43-1 \mid 60$ 


\title{
Three Churches in Trieste: for a Comparative Graphic Analysis
}

\author{
Alberto Sdegno \\ Silvia Masserano \\ Veronica Riavis
}

\section{Abstract}

The aim of the study was to analyze three architectural works that well express the proposed themes, namely the idea of connection, on the one hand, and the three concepts of language, distance and technology, on the other.

The research therefore envisaged the identification of three significant religious buildings, connected to each other by the same liturgical function, and by a strong bond in a spatial sense (being all built in the Trieste area) and temporal (built in less than twenty years after World War II). At the same time, characters with strong dissimilarity were found, both on the morphological level and on that of proximity / distance, and, finally, on the ways in which they were described figuratively, during the analysis of geometries and spatial configurations.

The three case studies -the Sanctuary to the Blessed Virgin Mary on Monte Grisa by Antonio Guacci, the church of the Immaculate Heart of Mary by Umberto Nordio and the parish center in Borgo San Sergio by Ernesto Nathan Rogers- therefore offer a significant example of synthesis of the dissimilar, which shows how the characters of a work can convey very different sensations, while insisting, in the same period of time, on the same territorial area and above all having the same function.

Keywords

Trieste, church, drawing, graphic analysis, digital modeling.

The three churches analysed: from the left: the the Blessed Virgin Mary on Monte Grisa by A. Guacci (graphic elaboration E. Widmar), the church of the Immaculate Heart of Mary by U. Nordio (graphic tion V. Riavis) the chure in Borgo S. Sergic by in Borgo S. Sergio by E.N. Rogers (graphic elaboration S. Masserano).
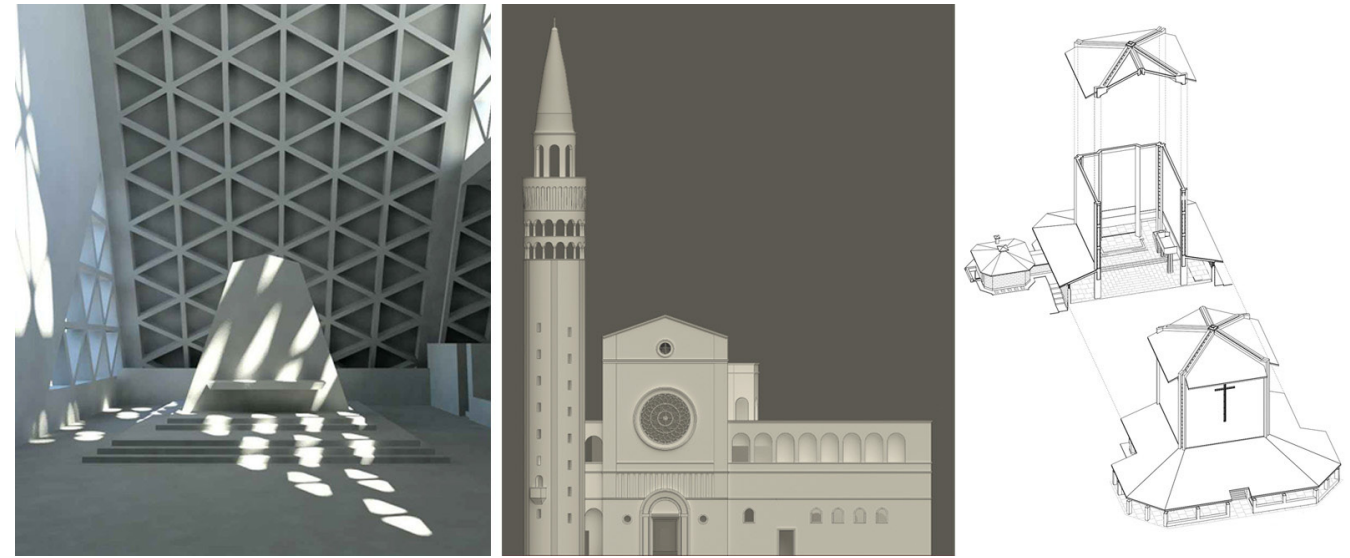


\section{Introduction}

Is it possible to interpret the three themes of language, distance and technology in an architectural sense? The opportunity is offered to us by a research currently underway on the building heritage of the twentieth century in the Trieste area, of which the work presented here is a first result. Following a cataloging of a large number of works, aimed at a graphic investigation of drawings and architectural form, three significant examples of the religious field have been identified, which offer well to represent the different declinations offered by the three themes. These are the sanctuary on Monte Grisa, the church of the Immaculate Heart of Mary and the church in Borgo San Sergio.

From the point of view of figurative language, they respond to very different linguistic canons, which greatly depend on the sensitivity of the designers. The sanctuary, in fact, is the work of Antonio Guacci, an engineer-artist attentive to the overall morphology of a work so as to underline the sculptural aspects that light and shadow determine on the form, as can also be seen in his other significant works, including $\mathrm{Cl}$ building in the Trieste university complex.

The second church, designed by Umberto Nordio -a prolific architect of this area- responds to more traditional canons, although declined with different shapes and materials. Longitudinal development of the nave, bell tower and accessory parts reflect the usual sensibilities of the period, also evident in other architectures, such as the main university building in Piazzale Europa. The third work is by one of the most influential architects of the twentieth century: Ernesto Nathan Rogers. Known for being one of the founders of the BBPR -formed, as well as by himself, by Gian Luigi Banfi (who will die in the Gusen concentration camp), Lodovico Barbiano di Belgiojoso and Enrico Peressutti- Rogers will get this work thanks to his Trieste origins, developing the solution that will then be implemented.

Although they were all built within a few years -indicatively between the fifties and the mid-sixties of the last century- they are very dissimilar to each other, so much so that even a comparison is difficult. This formal distance is also confirmed by their physical distance, since they are located in different points of the Trieste area. The sanctuary, in fact, is located north of the city, at about $330 \mathrm{~m}$ high, from which it is open to the gaze of all those who arrive in Trieste; The Immaculate Heart is in the city center, near the station and a few steps from Piazza Unità d'Italia, in the center of an ideal circumference having the distance between the other two case studies as a radius, that is, about ten kilometers. The Rogers church, in fact, is located in the suburban area south of the city, towards the Slovenian border in the direction of Koper.

From the point of view of technology, a clear differentiation was also chosen in terms of graphic analysis. In the first case it was decided to analyze the work using natural lighting simulation algorithms that could make explicit the intentions of the designer and the specific character of the work, through synthetic images that could emulate the perspective perception of the visitor.The sunlight, in fact, determines particular chiaroscuro effects that denote the architect's attention in the study of forms and the use of these algorithms allows us to virtually visit the architecture as if we were at various times of the year or of the day.

In the second case, we wanted to emphasize the plastic form of the work in order to enhance the individual elements -the main building, the cylindrical bell tower etc.- in an objective way, through the use of abstract representations with an improper projection center -orthogonal and axonometric- in the form of color images, to also emphasize the chromatic texture of the surfaces. In the third case, an even more abstract form was maintained- dictated by the simple drawing of lines- which could best interpret the sensibility of the designer and at the same time also describe those unrealized parts -such as the bell tower- of which we do not have detailed information about the surface color. The desire to subtract the work from a complete description of the materials had a further development in the creation of a solid model in rapid prototyping which, while allowing a physical materialization, would restore the shape in its geometric essentiality also through the use of a decomposition by parts of the architecture.

Although there is a strong connection between them due to the same design purpose -the carrying out of religious functions within them- the three works show dissimilar connotations on the three aspects we have considered -language, distance and technology- declined on the level that interests us most, that is to say the investigation sector of drawing. 


\section{The sanctuary to the Blessed Virgin Mary on Monte Grisa (I959-66)}

A strange, truncated pyramid shape is visible on the hilly crest of Monte Grisa to those who, traveling by train or car, arrive in Trieste. The position is certainly one of the most characteristic elements of the project, thanks to which the triangular serial content of the façade is certainly enhanced.

The events relating to the realization are well known, thanks to a series of contributions already published (Walker 1977, Guacci 199I). In a nutshell we recall that it is a temple dedicated to the Virgin Mary, to which its author, Antonio Guacci, has reserved a lot of energy. Although Umberto Nordio is also indicated among the authors, who in fact only coordinated the project, in reality Guacci must be considered the creator of the work, based on a double geometric matrix: the plan, in fact, is governed by a series of squares of 5 meters on each side, while the façade is made up of 288 isosceles triangles, having the particularity of having the base and the height equal to 2.5 meters. In this way square and triangle - despite being very different geometries- turn out to be mutually related to each other. It should also be remembered that the chosen triangle is made on the basis of the indications given by the mathematician Leonhard Euler in the 1700s, i.e. it is built recursively by joining the midpoints of the distances between the orthocenter and the vertices of a triangle having sides equal to a double of the sides of the triangle obtained, the latter being perfectly inserted in the center of the initial one.

The church is built as a cast-in-place reinforced concrete block, built thanks to the collaboration of Sergio Musmeci for the calculation of the structures and the approval of Adalberto Libera and Luigi Moretti, as members of the Pontifical Central Commission for Sacred Art in Italy, which on I I December 1963 approved the project, allowing it to be built.

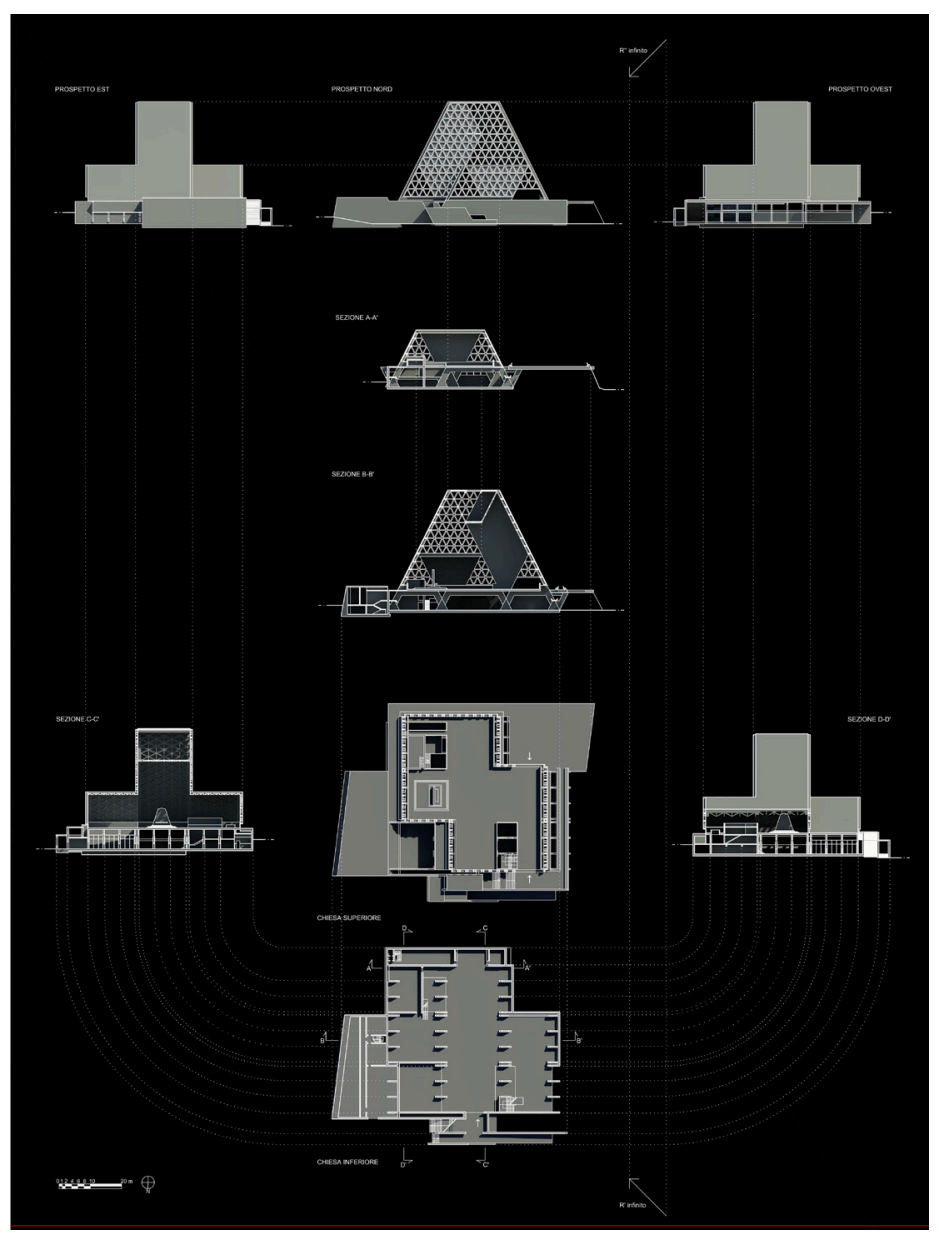


Fig. 2. System for the simulation of the natural light of the Marian Illumination algorithms graphic elaboration E. Widmar)

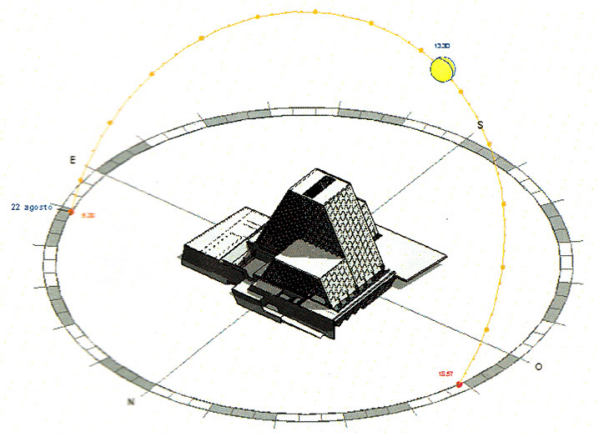

Among the significant elements it is worth mentioning the belfry which, facing inwards, constitutes a design novelty, not being placed in a top and external position as usually occurs with the inclusion in bell towers.

From the height of its 330 meters on the Karst edge, the Temple dominates the Gulf of Trieste and, despite being far from the city center, it is in fact one of the most loved works by Trieste citizens, thanks also to the extraordinary sensations that the play of lights transmits to the faithful throughout the year and day. A particularity that we wanted to analyze in detail with the use of advanced lighting algorithms that made it possible to simulate the sunlight that spreads on the altar at certain times of the year and day.

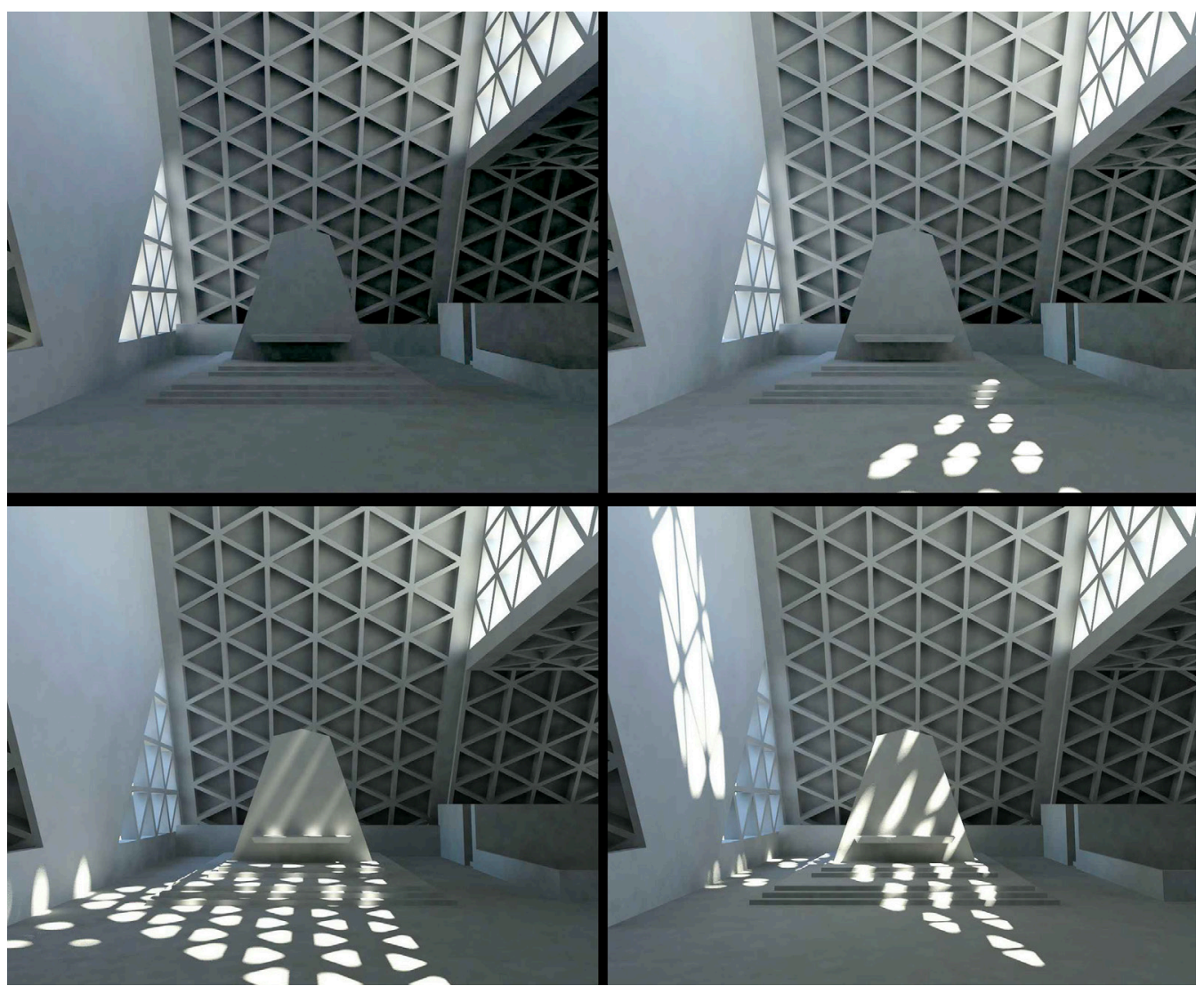

Fig. 3. Simulation of the natural light on the altar of the Marian Temple in various periods of the day with Global Illumination algorithms (graphic elaboration E. Widmar). 


\section{The church of the Immaculate Heart of Mary (1940-1955)}

At the corner of Sant'Anastasio and Manna streets is the church dedicated to the Immaculate Heart of Mary designed by Umberto Nordio ( 189 | - 197|). The Trieste architect, who graduated in Milan in 1919, designed various building. His work extended from the twenty years to the second post-war period, and sometimes his works suffered slowdowns caused by the world conflict as in the case of this church, whose general project was forwarded in 1940, with the consecration of the work in 1955, despite the fact that it was still incomplete of the bell tower completed in the seventies.

In this building Nordio integrates the twentieth century taste with the formal and functional characteristics of the basilica of the origins. Similarly to what has been applied to other design contexts, his architectures favor the composition of simple volumes, the contemporary reinterpretation of traditions dating back to different eras and the use of local raw materials. The basilica-plan church is divided into three naves with an apse ending. The environment is marked by arches supported by simple columns of an order similar to the Tuscan style without pedestal and entablature. The aisles are covered by cross and barrel vaults, while the central one has an elliptical section profile defined by ribs and arches. Without women's galleries, the central nave is illuminated by the high windows of the clerestory [I].

In the presbytery Nordio plans to insert a pulpit accessible by two simple side stairs, an element absent in the current configuration of the building.

The main façade on Sant'Anastasio street recalls the Romanesque basilicas: the gabled façade hides the internal conformation of the naves and a single splayed portal surmounted by the mosaic of the Virgin and Child introduces the building. The side elevation on Manna Street is instead marked by blind arches in correspondence with the spans of the aisles. On the outside, the horizontal cladding in stone ashlars is vertically interrupted by decora-

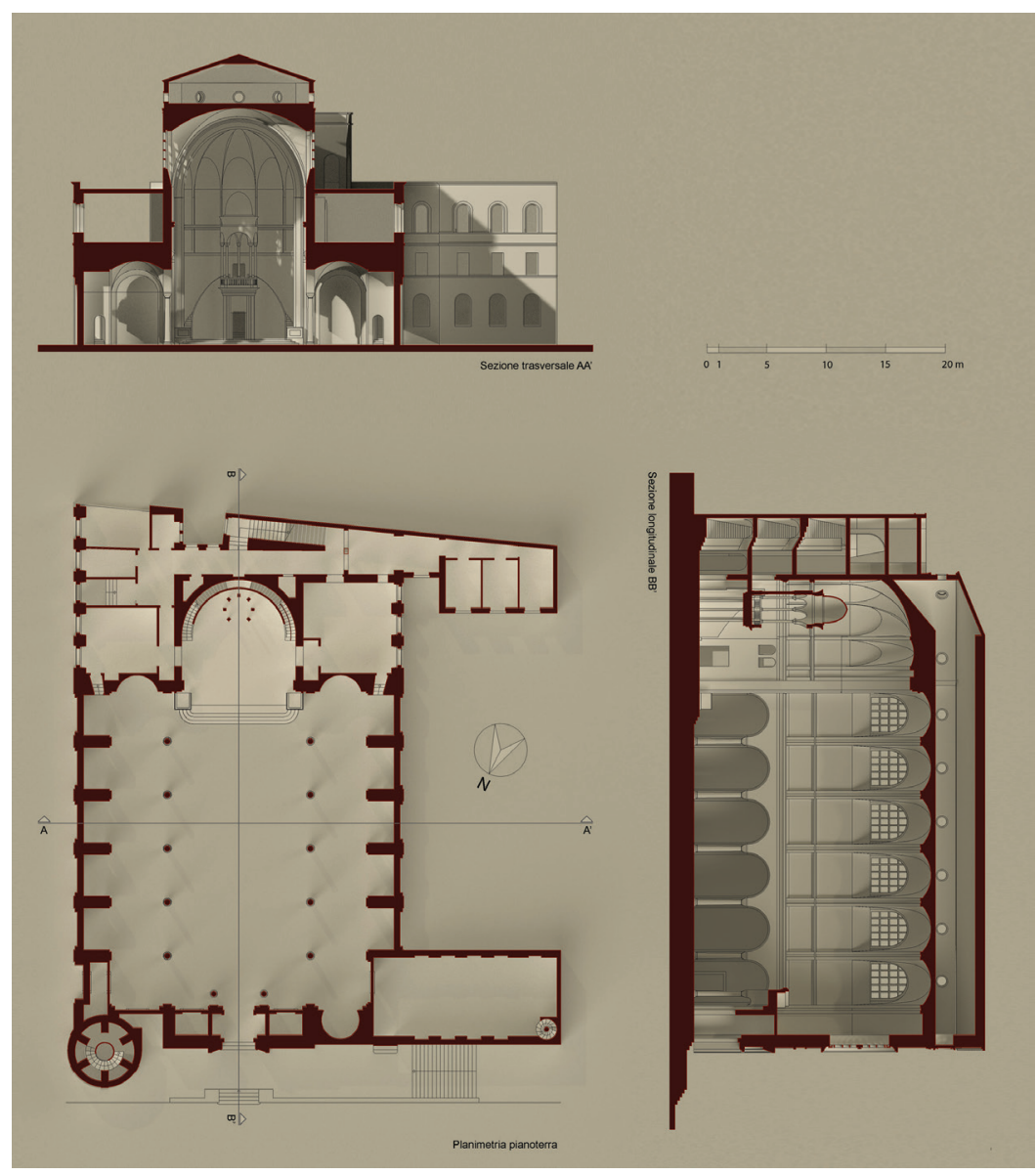


Fig. 5. Planimetric and altimetric sections of the church of the Immaculate Heart of Mary (graphic elaboration V. Riavis

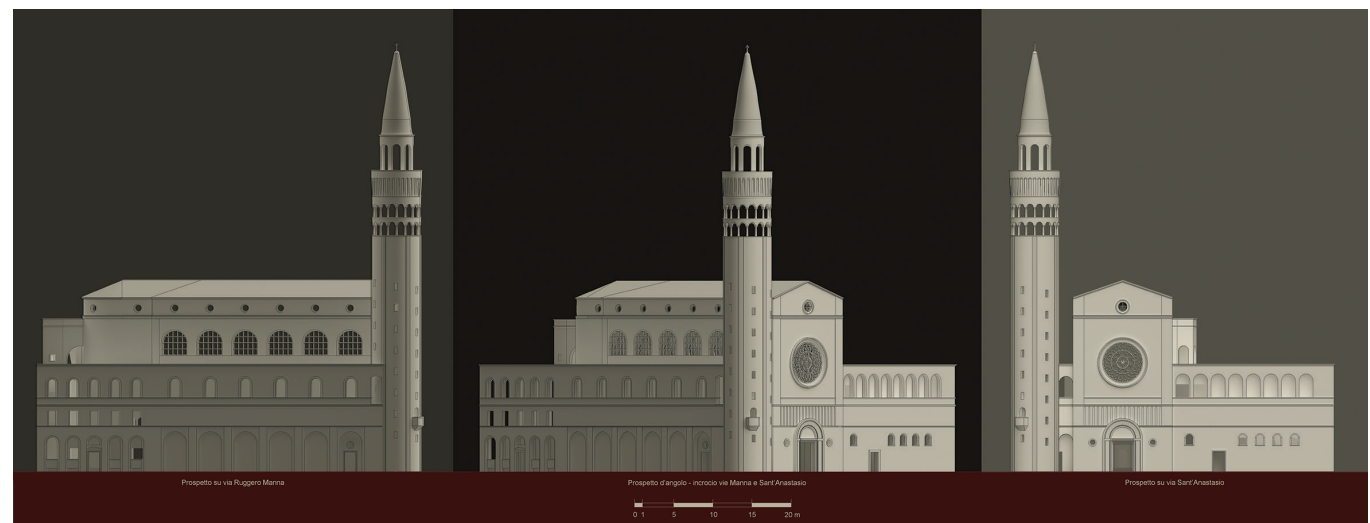

tive bands, but the attention is captured above all by the large rose window which seems to recall that of the Trieste Basilica of San Giusto, and by the high projecting bell tower with a circular plan that ends with several loggias.

The interesting geometries and design choices were highlighted by reconstructing the church and the adjoining convent based on the original drawings by Nordio. The modeling activity made it possible to better understand the distribution and interaction between the two spaces with different functions, but also to manage the digital model according to different views and to deepen its compositional and proportional characteristics, such as the structure of the spans or unrealized elements of the pulpit. The complexity of the building, its volumes and contents are made evident thanks to the use of parallel projections that allow the figures to be accompanied by a metric restitution, such as to allow the measurement of the drawings. Mongian projections and isometric orthogonal axonometries are able to best represent the morphological complexity of this significant architecture of Trieste.
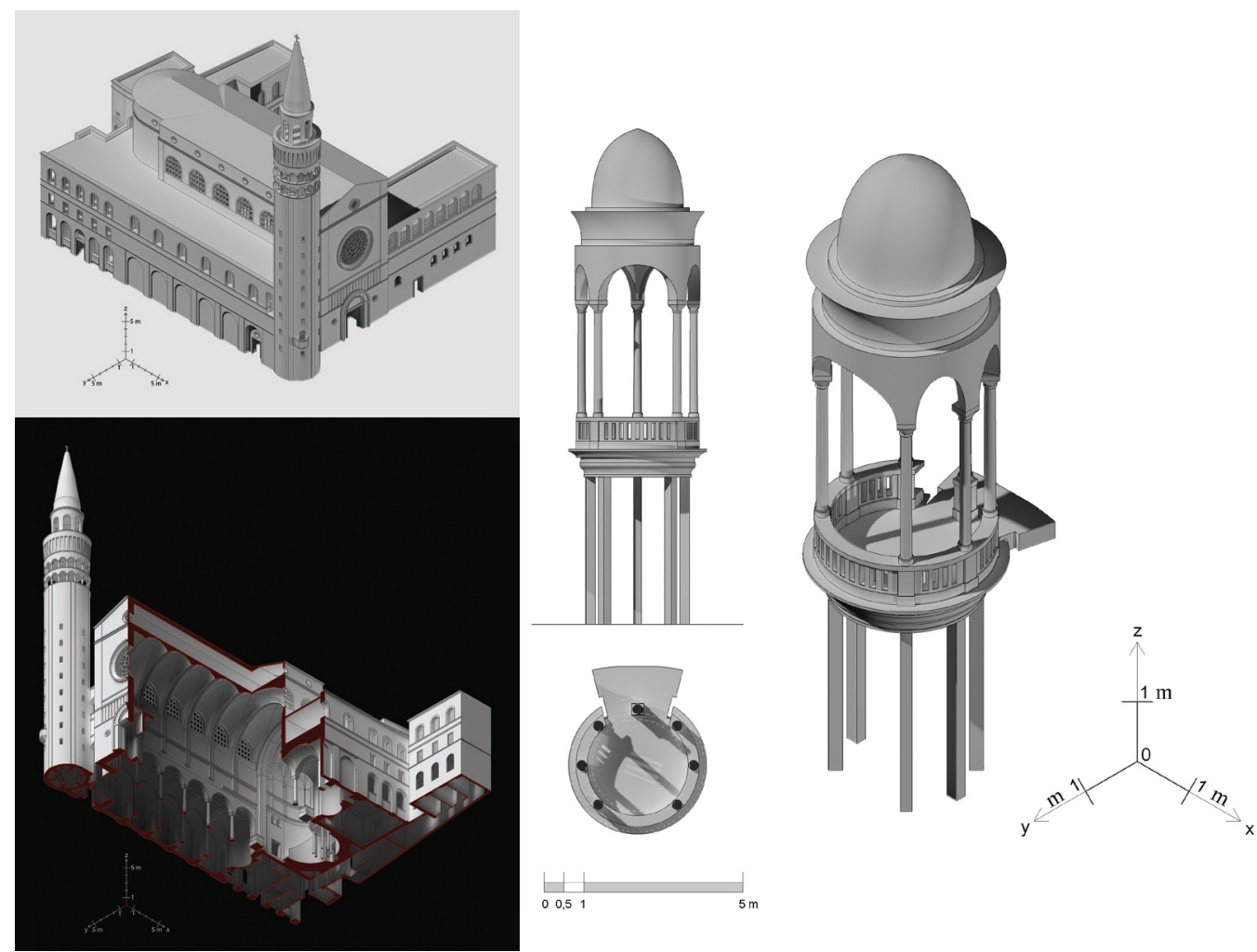

ig. 7. Orthogona axonometry of the project of the pulpit of the church of the Immaculate Heart of Mary (graphic elaboration V. Riavis) 


\section{The parish center of Borgo San Sergio (1954-1967)}

The project for the worker district of Borgo San Sergio, envisaged in 1949 by the Zoning Plan for the industrial area of Trieste, included, in addition to the construction of residential buildings, a pole of services. In the overall development of the plan, the BBPR dealt with the technical elaboration and partial execution of some elements of the community center and the church dedicated to San Sergio. The project for the liturgical building, put into operation in 1967, came to complete definition only at the end of a process marked by a sequence of five hypotheses drawn up by Ernesto Nathan Rogers.

A first idea of the church is expressed in a sketch drawn up in 1954 and broadly defines the building as an autonomous organism, in which a complex of volumes delimited by a portico are united by the development of the roof. The second proposal -dated 1955- configures the church through a polygonal structure flanked by a bell tower, while the third outlines in 1960 an organization close to the definitive solution, that is a building where two roofing systems conclude the hall with a single nave and a portico limited to the access area only, and where the conformation of the bell tower is reduced to a structural scaffolding. The fourth variant configures in 1961 a church enclosed by the intersection of a system of portals in which the entire volume is not translated as an immense and generic cubature, but as a differentiated and flowing reality where the light coming from the very large windows (one of the which designed to illuminate the altar) contributes to the achievement of this result; the bell tower is also modeled with the same structural scheme as the church, in an attempt to reduce the effects deriving from exposure to the bora wind. In 1962 the final version brought the church project to completion: in the fifth proposal the building, while remaining broadly unchanged compared to the $196 \mid$ solution, has some readjustments due to a greater definition of detail. The curtain wall of the portico is lowered, freeing the pillars that constitute the only support for the roofing of the portico. The transversal development of the planimetric system is dilated by adding a significant extension to the central basin, while the translation of the choir staircase towards the center of the presbytery allows the insertion of the ramps that vertically connect the interior of the nave. The flooring takes up the geometry of the classroom, emphasizing the diagonals of two hexahedra by means of tiles of different colors in correspondence with the projection of the space on the floor. A greater distance separates the double frames and increases the brightness resulting from

Fig. 8. Plan, sections and axonometric exploded view of the first version (1960) of the project by Ernesto Nathan Rogers for the church of Borgo S. Sergio (graphic elaboration S. Masserano).

Fig. 9. Plan, sections and axonometric exploded view of the second view of the second project for the church of project for the church of
Borgo S. Sergio (graphic elaboration S. Masserano).
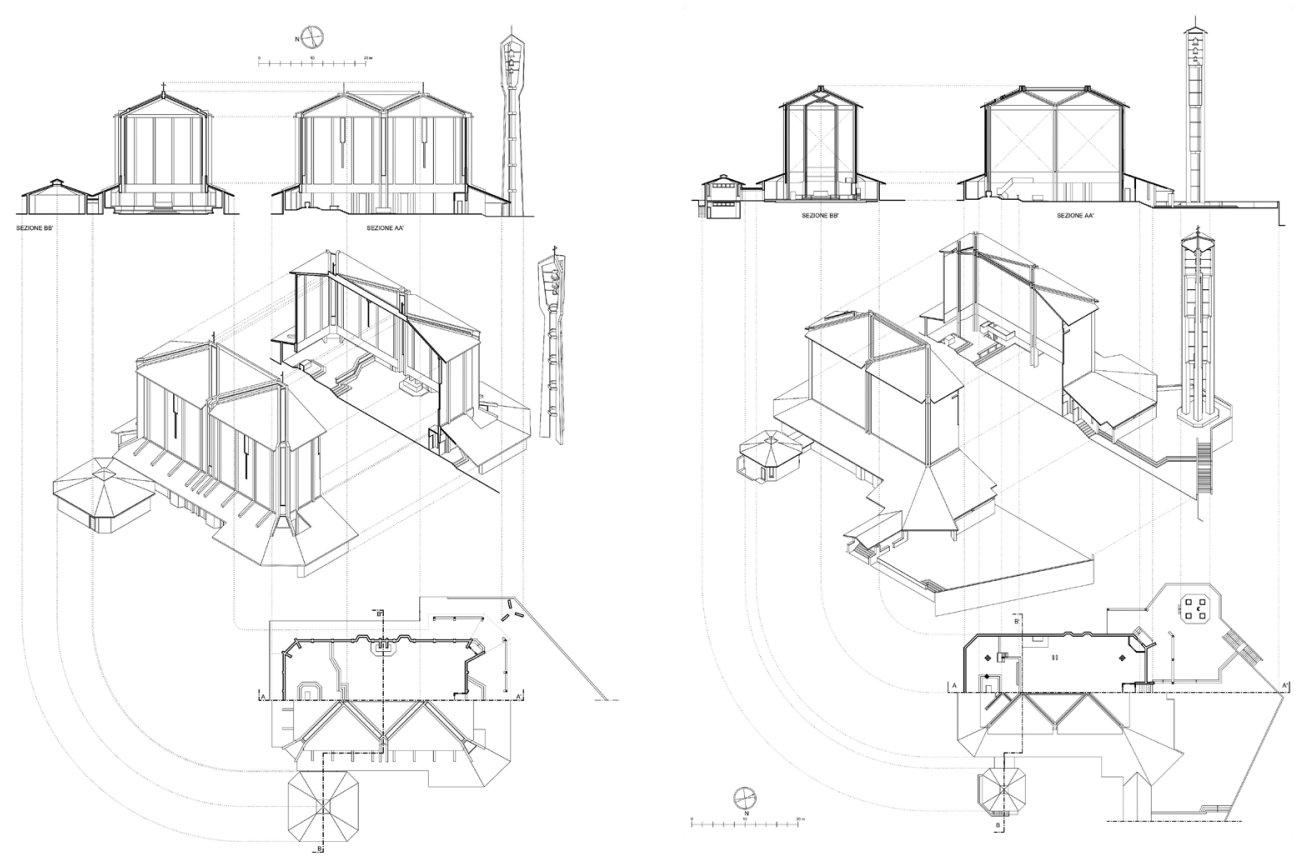
Fig. 10. Plan, sections and axonometric exploded view of the realised version (1962) of the church of Borgo S. Sergio (graphic elaboration S. Masserano).

Fig. 11. Cross-section and axonometric exploded view of the realised version (1962) of the church of Borgo S. Sergio (graphic elaboration S. Masserano).
Fig. 12. Cross-sectioned physical model of the built version (1962) of the church of Borgo S. Sergio realised with rapid prototyping techniques prototyping techniques
graphic elaboration S. Masserano).
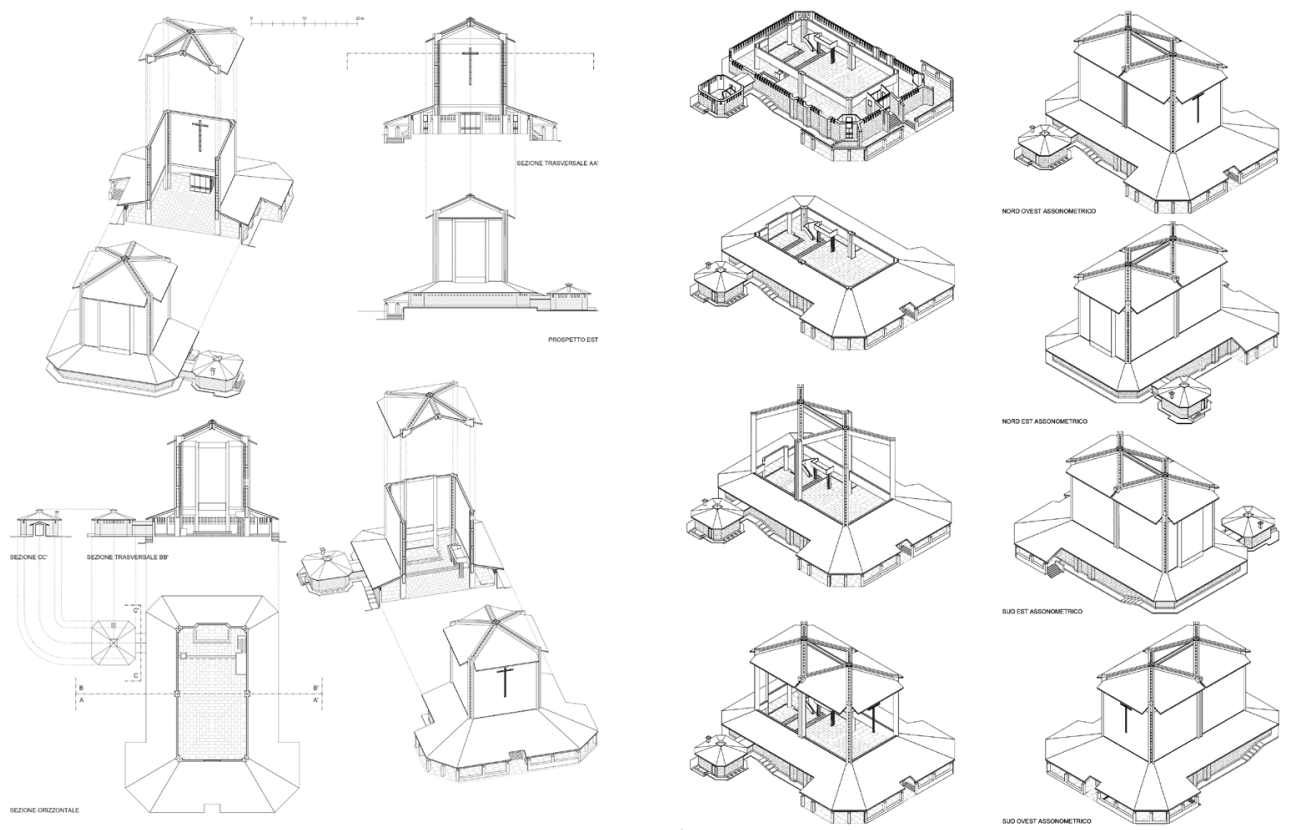

the use of a larger glass area. The amount of daylight in the ambulatory is amplified by the presence of a series of windows-slits to compensate for the shades generated by the presence, between the exposed concrete portals, of the double polychrome windows. The solution of the skylight above the altar is eliminated and with it the relative support structure. During implementation, alterations are made to the project and additional elements not anticipated by the graphical representations are added.

The reconstruction of the digital models of the last three proposals made it possible to visualize aspects that cannot be contemplated by the traditional graphic documentation and to fully grasp the evolution of a design idea, also by using the new rapid prototyping technologies that have provided further information for understanding the physical space.

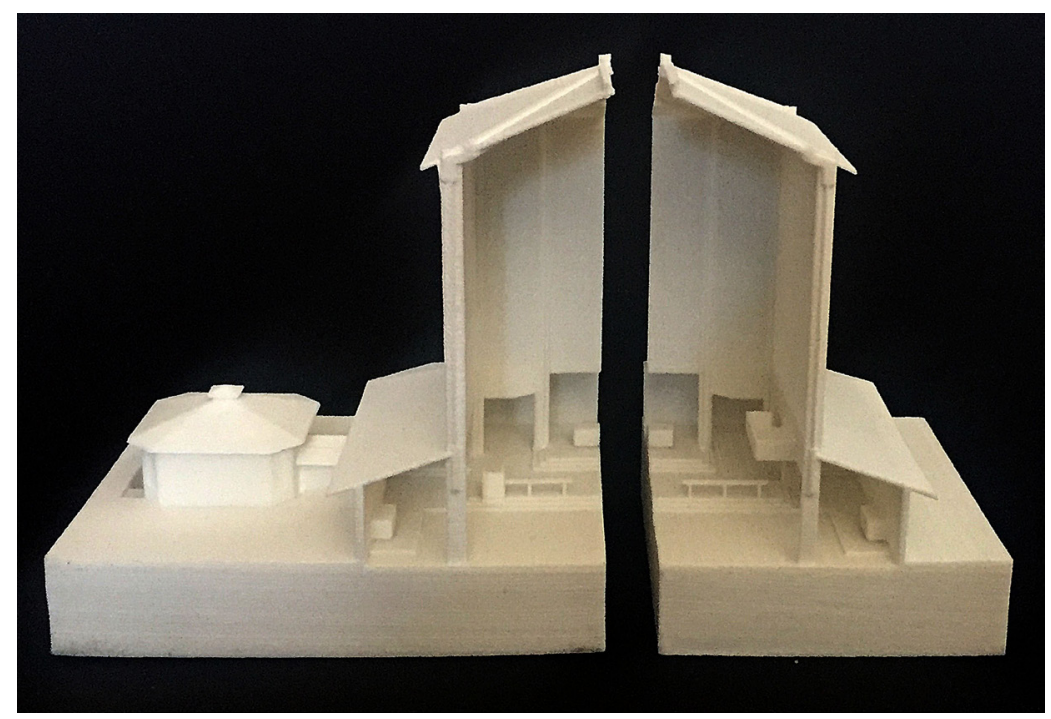




\title{
Conclusions
}

The analysis allowed us to compare three works with strong functional links -being three churches still consecrated for liturgical use- built in the Trieste area in the same historical period. As we have seen, however, their location is strongly dissimilar and above all they are characterized by a notable morphological difference. Tectonics, materials and geometry make them works with a strong distinctive character that we have tried to underline also figuratively with the use of advanced technologies, making use of simulation algorithms likely for Antonio Guacci's Temple, of synthetic images in parallel projection for the church of Umberto Nordio, and of line geometries -flanked by the materiality of a 3D print- for the parish center designed by Ernesto Nathan Rogers, so that the three concepts of language, distance and technology could be interconnected.

\section{Notes}

[I]The side aisles have no windows and are artificially lit.

\section{References}

Beari G. (1960). Guida alle chiese di Trieste e provincia.Trieste: Stab. Tipografico nazionale.

Ceiner G. (1998). Antonio Guacci. 1912-1995. II di-segno di una vita.Trieste: Lint.

Ceiner G. (2005). La creatività di Antonio Guacci tra arte e architettura. In L'archeografo triestino, vol. 65, n. I I 3, pp. 3 I 5-346.

Contessi G. (1981). Umberto Nordio. Architettura a Trieste 1926-1943. Milano: Franco Angeli.

Coppo D., Pozzetto, M. (a cura di) (1987). Disegni d'architettura di Antonio Guacci.Trieste:Tip.Villaggio del Fanciullo.

Cuscito G. (1982). Storia di Trieste Cristiana attraverso le sue chiese. Trieste:Vita nuova.

Guacci A. (1956). La storia ed i caratteri degli edifici. Trieste:Tip. Smolars.

Guacci A. (|99|). Il tempio di Monte Grisa a Trieste.Trieste: Del Bianco.

López Reus M. E. (2009). Ernesto Nathan Rogers. Continuità e contemporaneità. Milano: Marinotti.

Mainati E. (20 I8). Perché sorse il Tempio di Monte Grisa e i suoi primi passi. In L'Archeografo triestino, vol. 78, pp. 6-24.

Montesi P. (a cura di) (198I). Antonio Guacci. Disegni di architettura. Trieste: Edizioni Moderna.

Nicoloso P., Rovello F. (2005). Trieste 1918-1954. Guida all'architettura. Trieste: MGS Press.

Nordio U. (1955). Edilizia triestina vista da un architetto. Trieste:Tip. Giuliana.

Rogers E.N. (2006). Gli elementi del fenomeno architettonico. Milano: Marinotti.

Rogers E. N., Montesi P., Costa R. ( 1962). Tre interventi sul piano regolatore generale di Trieste. Udine: Del Bianco.

Sdegno A. (2012). Unbuilt Rogers. II disegno di progetti non realizzati dei BBPR. In C. Baglione (a cura di). Ernesto Nathan Rogers 1909-1 969. Milano: Franco Angeli.

Walcher M. (1989). II tempio mariano di Monte Grisa. La storia e l'architettura. Trieste: Italo Svevo.

Zerboni M., Moro L. (20 I6). La storia del Tempio nazionale di Monte Grisa dedicato a Maria Madre e Regina. Trieste: Luglioprint.

\begin{abstract}
Authors
Alberto Sdegno, Università degli Studi di Udine, alberto.sdegno@uniud.it

Silvia Masserano, Università degli Studi di Trieste, smasserano@units.it

Veronica Riavis, Università degli Studi di Udine, veronica.riavis@uniud.it.

To cite this chapter. Sdegno Alberto, Masserano Silvia, Riavis Veronica (2021). Tre chiese a Trieste: per un'analisi grafica comparativa/Three churches in Trieste: for a comparative graphic analysis. In Arena A., Arena M., Mediati D., Raffa P. (a cura di). Connettere. Un disegno per annodare e tessere. Linguaggi Distanze Tecnologie. Atti del $42^{\circ}$ Convegno Internazionale dei Docenti delle Discipline della Rappresentazione/Connecting. Drawing for weaving relationship. Languages Distances Technologies. Proceedings of the $42^{\text {th }}$ International Conference of Representation Disciplines Teachers. Milano: FrancoAngeli, pp. I | $43-1 \mid 60$.
\end{abstract}

